\title{
Clinical evaluation and reproductive indices of dairy cows naturally infected with Trypanosoma vivax
}

\section{Avaliação clínica e índices reprodutivos em vacas leiteiras naturalmente infectadas por Trypanossoma vivax}

\author{
Jael Soares Batista ${ }^{1 *}$; Carlos Iberê Alves Freitas ${ }^{1}$; Jardel Bezerra da Silva ${ }^{2}$; \\ Tania Vasconcelos Cavalcante ${ }^{3}$; Kaliane Alessandra Rodrigues de Paiva ${ }^{2}$; \\ Francisco Canindé Lopes ${ }^{2}$; Rodrigo Lira ${ }^{4}$
}

\begin{abstract}
The present study was aimed to assess the clinical changes and reproductive indices of dairy cows naturally infected with Trypanosoma vivax in a herd located in the Central Sertão of Ceará, Brazil. For the study, 40 animals were selected from a herd consisting of 210 dairy cows, and subdivided into two groups: group I, consisting of 20 cows naturally infected with $T$. vivax, and group II, consisting of 20 uninfected cows. Data on the parameters of reproductive efficiency were evaluated using a farm database (Propad Profissional GP®), in which the individual reproductive characteristics of the animals were stored. Data collected both before and after the outbreak were compared. The cows from group I showed a sudden drop in milk production, mucosal pallor, depression, anorexia, and a significant increase in rectal temperature and decreased hematocrit during the parasitemia outbreak. These clinical signs of the disease disappeared over time. However, T. vivax was detected by polymerase chain reaction (PCR) in animals with a negative parasitological test one year after the occurrence. Comparison of the reproductive index data for cows from groups I and II before and after the outbreak showed significant differences in first postpartum estrus, service period, and intervals between deliveries. In addition, repetition of estrus and abortion were significantly associated with $T$. vivax infection. Analysis of the reproductive indices of cows in groups I and II suggests that $T$. vivax infection decreased the reproductive efficiency of the study cows.
\end{abstract}

Key words: Cattle. Reproductive efficiency. Trypanosomiasis.

\section{Resumo}

O presente estudo teve como objetivos avaliar as alterações clínicas e os índices reprodutivos de vacas leiteiras infectadas naturalmente por Trypanosoma vivax em um rebanho localizado no sertão central do Ceará, Brasil. No rebanho, constituído por 210 vacas leiteiras, foram selecionados 40 animais, subdivididos em dois grupos: Grupo I, composto por 20 vacas infectadas naturalmente por T. vivax e o grupo II, composto por 20 vacas não infectadas. Os dados relativos aos parâmetros, que indicam eficiência reprodutiva dos dois grupos de animais, foram avaliados através de um banco de dados disponível na propriedade, por meio dos quais as características reprodutivas individuais dos

\footnotetext{
${ }^{1}$ Profs., Universidade Federal Rural do Semi-Árido, UFERSA, Mossoró, RN, Brasil. E-mail: jaelsoares@hotmail.com; iberefreitas@bol.com.br

2 Discentes, UFERSA, Mossoró, RN, Brasil. E-mail: jardelbezerra@bol.com.br; kalianepaiva@yahoo.com.br; fcoclopes@bol. com.br

${ }^{3}$ Prof $^{a}$, Universidade Federal do Piauí, UFPI, Teresina, PI, Brasil. E-mail: tania@ufpi.edu.br

${ }^{4}$ Pesquisador, UFERSA, Mossoró, RN, Brasil. E-mail: rodrigoalira@hotmail.com

* Autor para correspondência
} 
animais eram armazenadas em software Propad Profissional GP®, sendo as informações obtidas, comparadas tanto no período em que antecedeu o surto, quanto no que ocorreu após ele. As vacas do grupo I apresentaram durante o surto alta parasitemia, queda brusca da produção de leite, palidez de mucosas, depressão, anorexia, aumento significativo da temperatura retal e redução do hematócrito. Observou-se o desaparecimento dos sinais clínicos da enfermidade ao longo do tempo, no entanto, houve a confirmação do diagnóstico de T. vivax, através da Reação em Cadeia da Polimerase (PCR) em animais com exame parasitológico negativo um ano após a ocorrência. Quando comparados os dados dos índices reprodutivos das vacas do grupo I e do grupo II, no período em que antecedeu o surto, e no que ocorreu após o surto, verificou-se diferenças significativas para as variáveis: primeiro estro pósparto (PCPP/dias), período de serviço (PS-dias) e intervalo entre parto/dias (IEP). Houve associação significativa das variáveis, repetições de estro e abortamento com a infecção por T. vivax. A análise dos dados dos índices reprodutivos das vacas dos grupos I e II sugere que T. vivax diminuiu a eficiência reprodutiva dos animais avaliados.

Palavras-chave: Bovino. Eficiência reprodutiva. Tripanossomose.

\section{Introduction}

Trypanosoma vivax is an African pathogenic hemoparasite that causes a debilitating and usually fatal disease in domestic animals and ruminants. In most African countries, especially those south of the Sahara desert, where parasite transmission occurs through the biological vector the tsetse fly, trypanosomiasis has strong effect on reproductive and productive processes (STEVERDING, 2008). In South America, which lacks a biological vector, the parasite has adapted to mechanical transmission through hematophagous dipterans, including Stomoxys spp. and Tabanus spp. (SILVA et al., 2002).

In various South American countries, trypanosomiasis caused by infection with $T$. vivax shows different epidemiological conditions. The disease is enzootic in the main bovine and buffalo breeding regions of Venezuela (GARCÍA et al., 2006) and in the Colombian lowlands (OTTE et al., 1994), as well as Pantanal and the Brazilian Amazon; these biomes there exists an enzootic balance between host and parasite, that is most likely reached after outbreaks of serious illness. In these endemic regions, infected animals are oligosymptomatic, and the morbidity and mortality rates are very low (DÁVILA et al., 2003).

The opposite occurs in the semiarid region of the Brazilian Northeast, most likely because the environment is unfavorable to the development of vectors most of the year. Due to the occurrence of prolonged drought seasons and high temperatures, animals are not infected, and therefore, do not develop active immunity (BATISTA et al., 2007). Therefore, outbreaks occur more commonly during the rainy season, when the vector population increases, or when the animals in the semiarid region are transported to enzootically stable regions (BATISTA et al., 2012).

Recent studies on outbreaks of $T$. vivax infection in the Northeast region reported that the parasite is highly pathogenic, and that the disease is marked by high morbidity and mortality rates, decreased milk production, perinatal mortality, and reproductive disorders characterized by miscarriage, repetition of estrus, a higher stillbirth rate, weak calves, and anestrous (BATISTA et al., 2012; SILVA et al., 2013).

Given the occurrence of negative reproductive changes triggered by trypanosomiasis in infected Brazilian herds, this study aimed to assess the clinical changes and reproductive indices in dairy cows naturally infected with $T$. vivax.

\section{Materials and Methods}

The study was conducted on a dairy cattle farm with a history of natural $T$. vivax infection located in Mesorregião do Sertão Cearense, in the state of 
Ceará. The study area has a semiarid, hot, tropical climate, which is classified as BSw'h', according to the Köppen-Geiger climate classification system, with aim annual average temperature of $26^{\circ} \mathrm{C}$ to $28^{\circ} \mathrm{C}$ and annual average rainfall of $707.7 \mathrm{~mm}$ that is concentrated from February to April (CARMO FILHO et al., 1987).

The total herd consisted of 210 Guzolando ( $1 / 2$ Guzerat: $1 / 2$ Holstein) cows reared in a semi-intensive system, fed in cultivated pasture subdivided into paddocks used in a rotational system, and supplemented with corn-, soybean-, and mineral salt-based concentrate. The farm performs sanitary control of the herd, and all animals are vaccinated for clostridioses, foot-and-mouth disease, rabies, brucellosis, and leptospirosis. The cows were artificially inseminated with cryopreserved semen and mechanically milked twice daily.

To monitor the clinical progression and reproductive changes due to trypanosomiasis in the herd, the animals were allocated into two groups: group I, consisting of 20 cows naturally infected with $T$. vivax and group II, consisting of 20 uninfected cows.

To control the insect vectors and prevent infection with $T$. vivax, cows in group II were maintained in lots 2,000 meters apart from the animals in group I, with Diazinon- (30 g/100 g) and Chlorpyrifosbased (10 g/100 g, Expert@, MSD Saúde Animal, Brazil), long-acting, repellent ear tags, with two ear tags per animal that were changed monthly. After the disease was diagnosed on the farm, all positive animals were treated with Imizol ${ }^{\circledR}$ (4 mg per $\mathrm{kg}$, subcutaneous; MSD Saúde Animal, Brazil), except the animals in group I.

The animals in groups I and II were individually monitored, monthly, for a twelve-month period, from the beginning of the outbreak (July 2011), by assessing the following parameters: $T$. vivax infection, diagnosed by direct parasitological examination (blood smears of the leukocyte layer); parasitemia, determined according to the method described by Brener(1961); rectal temperature; heart and respiratory rates; apparent mucosal features; and hematocrit. A molecular diagnosis of infection was obtained at the beginning of the outbreak and one year later (July 2012) by polymerase chain reaction (PCR), according to the method of Cortez et al. (2009).

DNA preparations from blood samples were tested using a sensitive, T. vivax-specific PCR assay (TviCATL-PCR). DNA was extracted from the blood samples using the Wizard Genomic DNA purification Kit (Promega), and the following oligonucleotide primers directed against the gene encoding the cysteine protease cathepsin L (catL), DTO154 (forward): 5'-ACAGAATTCCAGGG CCAATGCGGCTCGTGCTGG-3' and DTO155 (reverse): 5'-TTAAAGCTTCCACGGTTCTTGA TGATCCAGTA-3', were used to amplify catL by PCR.

T. vivax infection was confirmed by amplification of a DNA fragment of approximately 177-bp. Selected samples were sequenced and aligned with the sequences of $T$. vivax isolates from the state of Paraíba. A catL (GenBank accession no. KR822728.1) fragment was used as a positive control. DNA samples from the blood of uninfected bovines were used as negative controls.

The number of trypanosomes in the peripheral blood of each animal was determined at the beginning of the outbreak and one year later as the band intensity of the 177-bp PCR amplification product, and the relative values were compared. The band intensity was visually classified as weak $(+)$, medium $(++)$, or strong $(+++)$, according to a modification of the method reported by Manso (2004).

The farm database, which stored data on the individual characteristics of the animals and was generated using prodap-profissional-gp ${ }^{\circledR}$ software, was used to evaluate the reproductive changes in the animals. In the analysis, the following parameters were assessed, first postpartum estrus (FPPE; in 
days), repetition of estrus (RC), service period (SP; in days), interval between deliveries (IBD; in days), and abortion rate (AR; per year). The reproductive data for the two groups of cows, T. vivax-infected and uninfected, were compared, as were data for the same cows at two different time periods, before the outbreak (July 2010 to June 2011; period I) and after the outbreak (October 2011 to August 2012; period II).

Data are expressed as mean and standard error and as simple frequencies and percentages calculated using SPSS statistical software (version 21.0, Statistics for Windows; IBM Corp., Armonk, NY). After investigation of the parametric assumptions, the statistical differences in the variables FPPE, SP, and IBD between experimental groups (infected and control) and within each experimental group were assessed using the Wilcoxon and Mann- and tests, respectively. The associations between categorical variables (e.g., abortion and RC) and T. vivax were assessed using the Chi-square and Fisher's exact tests. The latter was used when the value of the expected frequency was lower than 5 . P values less than 0.05 were considered significant.

This study was approved (Opinion No. 41/2011) by the Ethics Committee on Animal Use (Comissão de Ética no Uso de Animais - CEUA) of the Federal Rural University of the Semi-arid Region (Universidade Federal Rural do Semi-Árido UFERSA) and was performed in accordance with all ethical principles of animal care and use.

\section{Results}

During the first visit to the farm, T. vivax was identified in blood smears of the leukocyte layer obtained from 48 cows, which showed characteristic clinical signs of acute phase infection, including a sudden decrease in milk production, mucosal pallor, depression, anorexia, increased heart and respiratory rates, and parasitemia, which ranged from $1.8 \times 10^{5}$ to $140 \times 10^{5}$ trypomastigotes per $\mathrm{mL}$ of blood. The cows from group I also showed mean hematocrit values lower than those established for the species, which range from 26-42\% (FRANCIELLE et al., 2010), and were significantly different from the mean hematocrit values observed in the uninfected animals from group II. Similarly, the mean rectal temperature was higher than that established for the species, 38.0$39.3^{\circ} \mathrm{C}$ (SOUZA et al., 2007), and was significantly different from that observed in group II (Table 1).

Table 1. Parasitemia $\left(\times 10^{5}\right.$ trypanosomes per $\mathrm{mL}$ of blood), rectal temperature $\left({ }^{\circ} \mathrm{C}\right)$, and hematocrit $(\%)$ of dairy cows naturally infected with Trypanosoma vivax (GI) and uninfected cows (GII), at the beginning of the outbreak (July/2011). Values shown are mean \pm standard error.

\begin{tabular}{cccc}
\hline Variables & \multicolumn{2}{c}{ Experimental Groups } & \multirow{2}{*}{ Values p } \\
\cline { 2 - 3 } & GI & GII & $0,015^{*}$ \\
Parasitemia & $105,37 \pm 7,53$ & 0,0 & $0,008^{*}$ \\
Temperature & $41,2 \pm 0,05$ & $38,0 \pm 0,08$ & $0,007^{*}$ \\
Hematocrit & $19,6 \pm 0,54$ & $33,6 \pm 0,36$ & \\
\hline
\end{tabular}

*Statistical significance $(\mathrm{p}<0,05)$.

Blood samples collected from the cows from group I at the beginning of the outbreak showed the presences of T. vivax by PCR (TviCatL-PCR) as the amplification of a 177-bp T. vivax-specific DNA fragment. In contrast, the PCR was negative for all blood samples obtained from cows in the control group. The intensity of the amplified bands of the T. vivax DNA fragment at this period ranged from medium to strong.

During the fourth visit to the farm, no $T$. vivax was detected in blood smears, and there was no 
clinical evidence of trypanosomiasis in the animals from group I. In addition, the mean hematocrit and rectal temperature of the animals from this group were normal for the species and did not differ significantly from the mean values for the control animals (group II). A year after the outbreak began, the presence of T. vivax DNA in the blood of 16 cows from group I was confirmed by PCR. However, the intensity of the amplified bands were medium to weak. At the same time period, the PCR was negative for all blood samples obtained from control cows in group II.

Comparison of the reproductive index data for cows from groups I and II at the time period before the outbreak showed no significant differences in FPPE, SP, and IBD. However, significant differences in these variables were observed between the two groups at the time periods during and after the outbreak (Table 2).

The RC and AR were significantly associated with $T$. vivax infection because $83.3 \%$ of the 12 cows that repeated estrus belonged to group I, and $100 \%$ of the 6 cows that aborted also belonged to group I (Table 3).

Table 2. Reproductive indices of dairy cows naturally infected with Trypanosoma vivax (GI) and uninfected cows (GII) during the observation period. Values shown are mean \pm standard error.

\begin{tabular}{cccc}
\hline \multirow{2}{*}{ Ariables } & Experimental & \multicolumn{2}{c}{ Periods of analysis } \\
\cline { 3 - 4 } & Groups & Before outbreak & After outbreak \\
\cline { 3 - 4 } FPPE/days & GI & $42,15 \pm 0,46^{\mathrm{Ba}}$ & $56,17 \pm 2,85^{\mathrm{aA}}$ \\
& GII & $40,60 \pm 0,52^{\mathrm{aA}}$ & $41,15 \pm 0,47^{\mathrm{aB}}$ \\
\multirow{2}{*}{ SP/days } & GI & $106,35 \pm 2,47^{\mathrm{bA}}$ & $173,45 \pm 13,85^{\mathrm{aA}}$ \\
& GII & $103,31 \pm 2,05^{\mathrm{aA}}$ & $106,84 \pm 1,54^{\mathrm{aB}}$ \\
\multirow{2}{*}{ IBD/days } & GI & $376,30 \pm 2,94^{\mathrm{bA}}$ & $409,52 \pm 8,57^{\mathrm{aA}}$ \\
& GII & $374,10 \pm 1,86^{\mathrm{aA}}$ & $373,72 \pm 1,60^{\mathrm{aB}}$ \\
\hline
\end{tabular}

*Different lowercase letters in the line and upper case in the column means statistical difference $(p<0,05)$.

$\mathrm{FPPE}=$ first postpartum estrus; $\mathrm{SP}=$ service period; $\mathrm{IBD}=$ interval between deliveries.

Table 3. Frequency (\%) values for repetition of estrus and abortion in cows naturally infected with Trypanosoma vivax and uninfected cows during the observation period.

\begin{tabular}{ccccc}
\hline \multirow{2}{*}{ Variables } & \multicolumn{2}{c}{ Infection - after } & \multirow{2}{*}{ Total } & \multirow{2}{*}{ Values p } \\
\cline { 2 - 3 } Repetition of Estrus & Infected & Control & & \\
Yes & $10(83,3 \%)$ & $02(16,7 \%)$ & $12(100 \%)$ & \multirow{2}{*}{$0,016^{*}$} \\
No & $10(35,7 \%)$ & $18(64,3 \%)$ & $28(100 \%)$ & \\
Abortion & & & & \\
Yes & $06(100 \%)$ & $0(0,0 \%)$ & $06(100 \%)$ & $0,020^{*}$ \\
No & $14(41,2 \%)$ & $20(58,8 \%)$ & $34(100 \%)$ & \\
\hline
\end{tabular}

*Statistical significance $(\mathrm{p}<0,05)$.

\section{Discussion}

Theimpactoftrypanosomiasis on the reproduction of dairy cows was studied by comparing the clinical progression and indices of reproductive efficiency in cows naturally infected with $T$. vivax to these values in uninfected cows reared under the same conditions (sanitary, nutritional, and environmental management) on a farm on the interior of the state of Ceará. 
The results of the study showed that, at the beginning of the outbreak, naturally infected cows showed signs of clinical progression that are typical of the acute phase of trypanosomiasis, which were similar to those reported in most research studies on T. vivax, including high parasitemia, hyperthermia, anorexia, decreased milk production, and significant hematocrit reduction (MORAES, 2001; PELLÍN et al., 2003; BATISTA et al., 2006; ALMEIDA et al., 2010).

The combination of high parasitemia with the clinical manifestation of the disease is, according to Batista et al. (2006), typical of the recent penetration of the agent in enzootically unstable areas, wherein the animals had no prior contact with T. vivax, and therefore, lack immunity. Prophylaxis of trypanosomiasis includes breaking the vectortrypanosome-animal transmission chain (HAMILL et al., 2017). Early treatment causes the rapid transfer of mechanical transmission by insects, if this is the main mode of transmission, because parasitemia is always higher in the early stages of the disease (STEPHEN, 1986).

Monitoring of clinical progression on the farm showed the disappearance of clinical signs over time. However, T. vivax was detected by PCR in animals with negative parasitological examinations. After one year, the presence of chronically infected cows was confirmed, and these animals may be asymptomatic carriers, which are a key source of infection for non-carrier animals and those newly incorporated into the herd.

Comparison of the reproductive efficiency data for uninfected and infected cows collected both before and after the outbreak suggests that $T$. vivax infection adversely affected reproductive efficiency. Cows from the infected group showed significantly delayed onset of first postpartum estrus, and increased number of occurrences of repeated estrus, longer service periods, increased intervals between deliveries, and higher abortion rates. It should also be noted that the farm at which the present study was performed was state-of-the-art, and the hygiene, control, and nutritional management practices were considered satisfactory.

The reproductive data collected from these groups of cows may contribute to the future characterization of a situation that has not yet been evaluated in T. vivax-infected herds in Brazil, assessment of the impact of trypanosomiasis on reproduction in the chronic phase of infection when the clinical signs are not clear and direct methods of parasitological diagnosis fail to detect infection. The data collected in the present study indicate that, although parasitemia is absent, the adverse effects of infection on reproductive efficiency persist in chronically infected cows, and trypanosomiasis may remain as a subclinical disease in these animals, resulting in a silent loss in zootechnical performance.

According to Gutierrez et al. (2006), reproductive efficiency is the factor that has the greatest impact on herd productivity and profitability. Thus, our data collected in this retrospective study of cows, is concerning because the reproductive changes observed in $T$. vivax-infected cows may reduce fertility, resulting in adverse effects on production. The delayed occurrence of first postpartum estrus and the increased frequency of repetition of estrus, abortion rates, service periods, and even the lengthened interval between deliveries could lead to the permanence of cows infected in the herd without producing, thereby decreasing calf and milk production and increasing the maintenance costs of dry cows in the herd.

Trypanosomiasis is a disease with systemic effects, that can promote increased anestrous, impair fetal development, and interrupt pregnancy or impair lactation (RODRIGUES et al., 2013; SILVA et al., 2013). The etiopathogenic mechanisms involved in the reproductive changes in ruminants infected with T. vivax are poorly understood. Studies suggest that the reproductive disorders resulting from infection with these parasites occur for a number of reasons, including degeneration of the hypothalamus, pituitary glands, and gonads, with consequent 
changes in the plasma concentrations and secretion of hormones necessary for reproduction in both sexes (SEKONI, 1994). These reproductive changes in infected animals may have a multifactorial cause. Notably, T. vivax affects the normal metabolism of the animal, leading to a negative energy and protein balance, thereby promoting anemia, anorexia, hypoglycemia, and immunosuppression (STEPHEN, 1986; RODRIGUES et al., 2013; SILVA et al., 2013). A set of key endocrine, metabolic, and nutritional changes occur in gestating and lactating cows, with consequent effects on the general health status of the animal and subsequent reproductive efficiency (WOLTER, 1997). Under these circumstances, the adverse effects of trypanosomiasis are apparently severe, with key pathological clinical manifestations.

Rodrigues et al. (2013) evaluated ovary involvement in goats experimentally infected with $T$. vivax. The results clearly demonstrated that infected goats showed a significantly reduced number of normal follicles and a high rate of follicular degeneration when compared with the uninfected control group. The authors also detected the presence of $T$. vivax by PCR in the right and left ovaries of all goats from the infected group, suggesting participation of the parasite in the etiopathogenic mechanism of the reproductive damage commonly reported in infected animals.

Silva et al. (2013) experimentally infected sheep with $T$. vivax at different stages of pregnancy to assess the pathogenesis of reproductive failure. The infection was characterized by sheep death and perinatal death when infected in the first trimester of pregnancy and by abortion and perinatal death when infected in the last trimester of pregnancy. The following factors were shown to be possibly related to maternal reproductive failure: low body score, marked reduction of hematocrit and glucose, total protein, cholesterol, and progesterone serum levels.

\section{Conclusions}

The findings of the present study show that trypanosomiasis caused by $T$. vivax infection decreases the reproductive efficiency of dairy cows. This information demonstrates the need for more effective diagnosis and evaluating the reproductive life of infected animals, in addition to additional strategies for infection prevention and control.

\section{References}

ALMEIDA, K. S.; FREITAS, F. L. C.; TEBALDI, J. H.; ALESSI, A. C.; MACHADO, R. Z.; NASCIMENTO, A. A. Alterações clínicas, histopatológicas e enzimáticas em ovinos infectados experimentalmente por Trypanosoma vivax. Ciência Animal Brasileira, Goiânia, v. 11, n. 3, p. 669-676, set. 2010.

BATISTA, J. S.; RIET-CORREA, F.; BARBOSA, R. C.; GUERRA, J. L. Experimental infection by Trypanosoma vivax in sheep. Pesquisa Veterinária Brasileira, Rio de Janeiro, v. 26, n. 1, p. 31-37, mar. 2006.

BATISTA, J. S.; RIET-CORREA, F.; TEIXEIRA, M. M.; MADRUGA, C. R.; SIMÕES, S. D.; MAIA, T. F. Trypanosomiasis by Trypanosoma vivax in cattle in the Brazilian semiarid: description of an outbreak and lesions in the nervous system. Veterinary Parasitology, Amsterdam, v. 143, n. 2, p. 174-181, jan. 2007.

BATISTA, J. S.; RODRIGUES, C. M. F.; OLINDA, R. G.; SILVA, T. M. F.; VALE, R. G.; CÂMARA, A. C. L.; REBOUÇAS, R. E. S.; BEZERRA, F. S. B.; GARCÍA, H. A.; TEIXEIRA, M. M. G. Highly debilitating natural Trypanosoma vivax infections in Brazilian calves: epidemiology, pathology and probable congenital transmission. Parasitology Research, Ottawa, v. 110, n. 1, p. 73-80, maio 2012.

BRENER, Z. Contribuição ao estudo da terapêutica experimental da doença de Chagas. 1961. Tese (Doutorado em Livre-Docência) - Universidade Federal de Minas Gerais, Belo Horizonte.

CARMO FILHO, F.; SOBRINHO, J. E.; AMORIM, A. P. Dados meteorológicos de Mossoró: janeiro de 1898 a dezembro de 1986. Mossoró: ESAM/FGD, 1987. 325 p.

CORTEZ, A. P.; RODRIGUES, A. C.; GARCIA, H. A.; NEVES, L.; BATISTA, J. S.; BENGALY, Z.; PAIVA, F.; TEIXEIRA, M. M. Cathepsin L-like genes of Trypanosoma vivax from Africa and south 
America - characterisation, relationships and diagnostic implications. Molecular and Cellular Probes, Bochum, v. 23, n. 1, p. 44-51, fev. 2009.

DÁVILA,A. M. R.; HERRERA, H. M.; SCHLEBINGER, T.; SOUZA, S. S.; TRAUB-CSEKO, Y. M. Using PCR for unraveling the cryptic epizootiology of livestock trypanosomosis in the Pantanal, Brazil. Veterinary Parasitology, Amsterdam, v. 117, n. 2, p. 1-13, nov. 2003.

FRANCIELLE, B.; CURTINAZ, A. S.; SCHWEGLER, E.; SCHMITT, E. Efeito da anaplasmose na produção de leite durante o pós-parto de vacas leiteiras. In: CONGRESSO DE INICIAÇÃO CIENTÍFICA, 19; ENCONTRO DE PÓS-GRADUAÇÃO E A II MOSTRA CIENTÍFICA, 12., 2010, Pelotas. Anais... Pelotas: UFPEL, 2010. p. 1-4.

GARCÍA, H.; GARCÍA, M. E.; PÉREZ, G.; BETHENCOURT, A.; ZERPA, E.; PÉREZ, H.; MENDONZA-LEÓN, A. Trypanosomiasis in Venezuelan water buffaloes: association of packed-cell volumes with seroprevalence and current trypanosome infection. Annals of Tropical Medicine and Parasitology, London, v. 100, n. 4, p. 297-305, 2006.

GUTIERREZ, C.; CORBERA, J. A.; MORALES, M.; BÜSCHER, P. Trypanossomosis in goats: currents status. Annals of the New York Academy of Sciences, New York, v. 1081, n. 1, p. 300-310, nov. 2006.

HAMILL, L.; PICOZZI, K.; FYFE, J.; WISSMANN, B. V.; WASTLING, S.; WARDROP, N.; SELBY, R.; ACUP, C. A.; BARDOSH, K. L.; MUHANGUZI, D.; KABASA, J. D.; WAISWA, C.; WELBURN, S. C. Evaluating the impact of targeting livestock for the prevention of human and animal trypanosomiasis, at village level, in districts newly affected with $\mathrm{T}$. b. rhodesiense in Uganda. Infectious Diseases of Poverty, Pequim, v. 6, n. 1, p. 1628, fev. 2017.

MANSO, M. R. F. C. Aplicação da reação em cadeia da polimerase (PCR) no diagnóstico de malária. 2004. Dissertação (Mestrado em Doenças Tropicais e Infecciosas) - Universidade do Estado do Amazonas, Manaus.

MORAES, M. A. V. Trypanosoma vivax: infecção experimental em bovinos (Bos indicus). 2001. Dissertação (Mestrado em Medicina Veterinária, Patologia Animal) Universidade Estadual Paulista, Jaboticabal.
OTTE, M. J.; ABUABARA, J. Y.; WELLS, E. A. Tripanosoma vivax in Colombia: epidemiology and production losses. Tropical Animal Health and Production, Roslin, v. 26, n. 3, p. 146-156, out. 1994.

PELLÍN, C. E. S.; GONZÁLEZ, F. A. G.; BALDIZÁN, G.; LINAREZ, F. F. M. Comportamiento parasitológico, clínico y hematológico em ovinos infectados experimentalmente con un aislado venezolano de Trypanosoma vivax. Revista Científica Veterinaria Tropical, Ibadan, v. 28, n. 1, p. 79-92, jun. 2003.

RODRIGUES, C. M. F.; OLINDA, R. G.; SILVA, T. M. F.; VALE, R. G.; SILVA, A. E.; LIMA, G. L.; GARCIA, H. A.; TEIXEIRA, M. M.; BATISTA, J. S. Follicular degeneration in the ovaries of goats experimentally infected with Trypanosoma vivax from the Brazilian semi-arid region. Veterinary Parasitology, Amsterdam, v. 191, n. 2, p. 146-153, ago. 2013.

SEKONI, V. O. Reproductive disorders caused by animal trypanosomiases: a review. Theriogenology, Oxford, v. 42, n. 4, p. 557-570, set. 1994.

SILVA, R. A. M. S.; SEIDL, A.; RAMIREZ, L.; DÁVILA, A. M. R. Trypanosoma evansi e Trypanosoma vivax: biologia, diagnóstico e controle. $21^{\text {th }}$ ed. Corumbá: Embrapa Pantanal, 2002. 141 p.

SILVA, T. M. F.; OLINDA, R. G.; RODRIGUES, C. M. F.; CÂMARA, A. C. L.; LOPES, F. C.; COELHO, W. A. C.; RIBEIRO, M. F. B.; FREITAS, C. I. A.; TEIXEIRA, M. M. G.; BATISTA, J. S. Pathogenesis of reproductive failure induced by Trypanosoma vivax in experimentally infected pregnant ewes. Veterinary Research, Jouy-enJosas, v. 44, n. 1, p. 1-9, jan. 2013.

SOUZA, B. B.; SILVA, R. M. N.; MARINHO, M. L.; SILVA, G. A.; SILVA, E. M. N.; SOUZA, A. P. Parâmetros fisiológicos e índice de tolerância ao calor de bovinos da raça Sindi no semi-árido paraibano. Ciência e Agrotecnologia, Lavras, v. 31, n. 3, p. 883-888, jun. 2007.

STEPHEN, L. E. Trypanosomisis: a veterinary perspective. Oxford: Pergamon Press, 1986. 551 p.

STEVERDING, D. The history of African trypanosomiasis. Parasites \& Vectors, Norwich, v. 3, n. 1, p. 1-8, fev. 2008.

WOLTER, R. Alimentattion de la vache laitière. Paris: Ed. France Agricole 3ème edition, 1997. 273 p. 